\title{
NON-LINEAR ANALYSIS OF SUSPENSION BRIDGES WITH FLEXIBLE AND RIGID CABLES
}

\author{
Algirdas Juozapaitis ${ }^{1}$, Siim Idnurm ${ }^{2}$, Gintaris Kaklauskas ${ }^{3}$, Juhan Idnurm ${ }^{4}$, Viktor Gribniak ${ }^{5}$ \\ 1,3,5 Department of Bridges and Special Structures, Vilnius Gediminas Technical University, \\ Saulètekio al. 11, 10223 Vilnius, Lithuania \\ ${ }^{2}$ Department of Bridge Constructions, Tallinn University of Technology, Ehitajate 5, 19086 Tallinn, Estonia \\ ${ }^{4}$ Department of Transportation, Tallinn University of Technology, Ehitajate tee 5, 19086 Tallinn, Estonia \\ E-mails: ${ }^{1}$ Algirdas.Juozapaitis@vgtu.lt; ${ }^{2}$ Siim.Idnurm@ttu.ee; ${ }^{3}$ Gintaris.Kaklauskas@vgtu.lt; \\ ${ }^{4} j i @$ estpak.ee; ${ }^{5}$ Viktor.Gribniak@vgtu.lt \\ Received 21 Dec. 2009; accepted 20 Feb. 2010
}

\begin{abstract}
One of the main problems related to the design of suspension bridges is stabilisation of their initial form. The tendency of suspension bridges to deform is generally determined by the kinematical displacements of the suspension cable caused by asymmetrical loads rather than by the elastic deformations. There are some suspension bridges when the socalled rigid (stiff in bending) cables instead of usual flexible cables are suggested for stabilisation of their initial form. The analysis methods of such suspension bridges with rigid cables are underdeveloped. For the analysis of classical suspension bridges analytical models can be applied. However, in case of concentrated forces, the numerical techniques are preferred. The article presents analytical expressions for the calculation of internal forces and displacements of suspension bridges with a rigid cable. The article also discusses the discrete calculation model for classical suspension bridges.
\end{abstract}

Keywords: suspension bridge, flexible cable, rigid cable, non-linear analysis, continual model, discrete model, internal forces and displacements.

\section{Introduction}

For many years, suspension bridges have an exclusive place among other structural systems due to their efficiency and remarkable architectural appearance (Troyano 2003). Due to the dominating tension stresses, suspension bridges assure covering the longest spans in the world (Ryall et al. 2000; Gimsing 1997). However, one of the main peculiarities of the suspension bridges is the tendency of having large exessive deformations (Katchurin et al. 1971; Gimsing 1997). Such tendency to deform is generally determined by kinematical displacements caused by asymmetrical loads rather than by elastic deformations of the suspension cable (Kulbach 2007; Juozapaitis \& Norkus 2004). As shown in Fig. a, the stiffening girder is the main structural element that ensures the required stiffness of classical suspension bridges. A number of additional structural hints, which help to reduce the displacements of kinematical origin, are also known (Katchurin et al. 1971; Jennings 1987; Gimsing 1997). However, some of them are rather complex or are ineffective from the technical and economic perspective. Quite a number of publications analyse the behaviour of classical suspension bridges when the suspension cable is considered ideally flexible (Cobo del Arco \& Aparicio 2001; Wollman 2001; Kulbach et al. 2002). However, this idealisation is a purely theoretical concept, as in real structures such elements have a certain height of the cross-section and, consequently, a bending stiffness of a finite (not equal to zero) value (Furst et al. 2001). There are some publications that analyse the stress-strain state in flexible cables of suspension bridges taking into account their local bending stiffness that exists in certain sections (Gimsing 1997; Prato \& Ceballos 2003). It must be noted that the so-called rigid cables $\left(E_{\mathrm{c}} J_{\mathrm{c}}>0\right.$, see Fig. b) are used to reduce the kinematical displacements of suspended structures (Moskalev \& Popova 2003; Muschanov et al. 2005; Juozapaitis et al. 2008). Such suspended structural elements are made from the standard hot rolled or welded sections, which simplify their construction and assembly. Besides, these sections have higher fatigue resistance (Kala 2008). A modern structural scheme of the suspension bridges allows stabilising the initial form and ensuring the required stiffness of the bridge by introducing the rigid cables (Grigorjeva et al. 2004; Juozapaitis et al. 2006). Calculation methods for such suspension bridges are scarce. A simplified engineering technique has been proposed by Grigorjeva et al. (2006) for predicting displacements of suspension bridges with rigid cables subjected to symmetrical or asymmetrical external loading. The technique is useful for conceptual, rough analysis of such bridges. However, this method (based on a girder idealisation) cannot be considered sufficiently accurate. Numerical methods (Mang 2009) are often used for more advanced analysis of suspension bridges with rigid cables (Nevaril \& Kytyr 2001). 

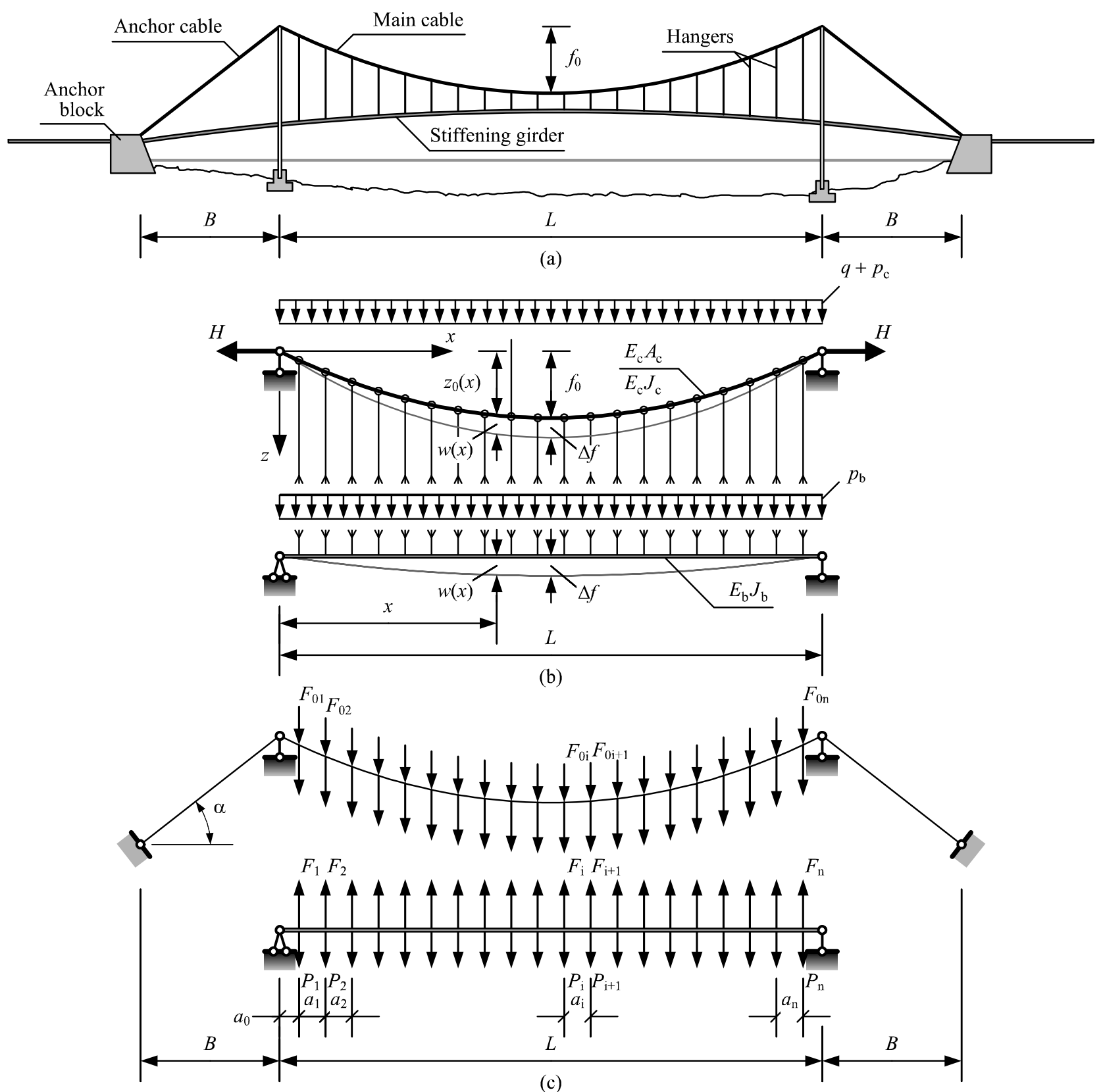

(c)

Fig. Calculation model for a suspension bridge

Certainly, it is relevant to develop an accurate analytical calculation technique for suspension bridges with rigid cables. The behaviour of classical suspension bridges is analysed based on the assumption that the hangers transfer a uniformly distributed load to the cable. However, this assumption sometimes can not be applied in the cases of relatively long distance between the hangers or considerable concentrated forces. A discrete calculation model is applied in such cases (Kulbach et al. 2002).

This article discusses the stress-strain analysis of a classical suspension bridge with a flexible cable. The analysis is extended for the case of a suspended bridge having a modern structural scheme with a rigid cable. Analytical expressions for calculation of such bridges are presented. Applying of the fictitious displacement concept allowed reducing the amount of iterative calculations in the proposed procedure. The discrete calculation model for a classical suspension bridge is also presented.

\section{Static Analysis of a Suspension Bridge}

The structural scheme of a classical single-span suspension bridge that consists of a flexible cable, a stiffening girder, hangers, pylons and anchor cables is shown in Fig. a. The analysis of such bridges concerning the nonlinear structural behaviour is a complex task (Gimsing 1997; Kulbach 2007). Therefore, the equilibrium conditions for classical suspension bridges are formulated on the basis of certain assumptions: (a) the main cable is absolutely flexible and has a square parabola as its initial shape when the bridge is subjected to the dead load only; (b) all structural elements are made from ideally elastic 
materials; (c) the elastic elongation and horizontal displacements of the hangers can be neglected; (d) the height as well as the bending stiffness of the stiffening girder is constant along the entire span of the bridge $\left(h_{\mathrm{b}}=\right.$ const $E_{\mathrm{b}} J_{\mathrm{b}}=$ const ); (e) the number of hangers and the distance between them allow the load acting on the cable to be considered as uniformly distributed.

The transfer route of loads acting on the bridge (the load history) is also specified: the entire dead load $g$ acts on the cable, while the live load $p$ is carried both by the stiffening girder $p_{\mathrm{b}}$ and the cable $p_{\mathrm{c}}$.

\subsection{Analysis of a classical suspension bridge}

The design scheme of a classical suspension bridge affected both by the dead load $g$ and the live load $p$ is shown in Fig. b. The main cable is subjected to couple action of the dead load and part of the live load $\left(g+p_{\mathrm{c}}\right)$, while the stiffening girder is affected only by part of the live load $\left(p_{\mathrm{b}}\right)$. The cable of a classical bridge is assumed to be ideally flexible $\left(E_{\mathrm{c}} J_{\mathrm{c}}=0\right)$.

The initial state of the cable, when it is subjected to the dead load $g$ only, may be defined by the following equation:

$$
H_{0} \cdot z_{0}(x)=M_{\mathrm{g}}(x) .
$$

Here $H_{0}$ is the horizontal component of the cable tension force when the dead load $g$ is acting; $M_{\mathrm{g}}(x)$ is the bending moment of an equivalent girder (the same span length) due to load $g$.

The live load $p$ applied on the bridge strains both the cable and the stiffening girder. Considering the assumption (c), we can write the equation for vertical displacements of the stiffening girder and the cable: $w_{\mathrm{b}}(x)=w_{\mathrm{c}}(x)=w(x)$. The equilibrium condition of the flexible cable is as follows:

$$
H\left[z_{0}(x)+w(x)\right]+M_{\mathrm{c}, \mathrm{g}+\mathrm{p}}(x)=0 .
$$

Here $H$ is the horizontal component of the cable tension force in the main cable due to the dead and live loads; $M_{\mathrm{c}, \mathrm{g}+\mathrm{p}}(x)$ is the bending moment of an equivalent girder due to complex loading on the cable $\left(g+p_{\mathrm{c}}\right)$.

The equilibrium condition of the stiffening girder subjected to the live load may be expressed using the following differential equation:

$$
-E_{\mathrm{b}} J_{\mathrm{b}} \cdot w^{\prime \prime}(x)+M_{\mathrm{b}, \mathrm{p}}(x)=0 .
$$

Here $E_{\mathrm{b}} J_{\mathrm{b}}$ is the bending stiffness of the girder; $M_{\mathrm{b}, \mathrm{p}}(x)$ is the bending moment of an equivalent girder due to live load $\left(p_{\mathrm{b}}\right)$.

Considering the assumption (c) and the equations (2) and (3), the differential equation can be written:

$$
E_{\mathrm{b}} J_{\mathrm{b}} \cdot w^{\prime \prime}(x)-H\left[z_{0}(x)+w(x)\right]+M_{\mathrm{g}+\mathrm{p}}(x)=0 .
$$

Here $M_{\mathrm{g}+\mathrm{p}}(x)$ is the bending moment of an equivalent girder due to dead load and live load $(g+p)$ acting on the entire bridge.
It should be noted that the stress-strain state of suspension bridges can be defined using the differential equation (Kulbach 2007; Wollman 2001). However, solution of such equation frequently is rather complex. Simplifying the solution procedure, equation (4) can be rewritten as follows:

$$
w^{\prime \prime}(x)-k^{2} w(x)=k^{2}\left[z_{0}(x)-M_{\mathrm{g}+\mathrm{p}}(x) / H\right] .
$$

Here $k^{2}=H / E_{\mathrm{b}} J_{\mathrm{b}}$ is the flexibility parameter.

The ratio $z_{\mathrm{fic}}(x)=M_{\mathrm{g}+\mathrm{p}}(x) / H$ represents the fictitious curvature of the deformed axis of the ideally flexible cable subjected to loads $g+p$ (Moskalev \& Popova 2003). Then, equation (5) can be rearranged as follows:

$$
w^{\prime \prime}(x)-k^{2} w(x)=-k^{2} \cdot w_{\text {fic }}(x) .
$$

Here $w_{\text {fic }}(x)=z_{\text {fic }}(x)-z_{0}(x)$ is the fictitious displacement of the cable.

The equation above can be solved assuming that the bridge is subjected to uniformly distributed load ( $g, p=$ const ) and taking into consideration the boundary conditions

$$
\begin{gathered}
w(x)=\Delta f_{\text {fic }}\left[\frac{4 x}{L}-\frac{4 x^{2}}{L^{2}}+\frac{8 X}{k^{2} L^{2}}\right] \\
X=\operatorname{chk} L-\frac{1-\operatorname{chk} L}{\operatorname{shk} L} \cdot \operatorname{shk} L-1 .
\end{gathered}
$$

Here $\Delta f_{\text {fic }}$ is the fictitious displacement of the cable in the middle of the span.

It should be noted that equation (7) is equivalent to the equation used in the calculations of displacements of individual rigid cables $(E J \neq 0)$ (Moskalev \& Popova 2003; Juozapaitis et al. 2006). It means that the behaviour of a classical suspension bridge can be defined by the behaviour of a rigid cable obtained as a result of the synthesis between a flexible cable and a girder.

The main unknowns in equation (7) are the fictitious displacement $\Delta f_{\text {fic }}$ and the tensile force in the cable $H$. Some additional equations should be introduced in order to find these parameters. Let us use the dependence which we know from the analysis of suspension structures:

$$
\begin{gathered}
s=s_{0}+\Delta s_{\mathrm{el}} \\
L+0,5 \int\left[w^{\prime}(x)\right]^{2} d x=\left[L+\frac{8 f_{0}^{2}}{3 L}\right]+\frac{\left(H-H_{0}\right) s_{0}}{E_{\mathrm{c}} A_{\mathrm{c}}} .
\end{gathered}
$$

Here $s_{0}$ is the initial length of the cable; $\Delta s_{\mathrm{el}}$ is the elastic elongation of the cable and $s$ is the length of the deformed cable.

The unknowns ( $H$ and $\Delta f_{\text {fic }}$ ) are defined using the gradual approximation. Introduction of the fictitious displacement leads to the reduction of the number of iterations by considerable amounts. When the values $H$ and $\Delta f_{\text {fic }}$ are known, we can calculate the real displacements $w(x)$ of the bridge and the bending moment of the girder $M_{\mathrm{b}}(x)=-E_{\mathrm{b}} J_{\mathrm{b}} \cdot w^{\prime \prime}(x)$. 


\subsection{Analysis of a suspension bridge with a rigid cable}

It should be noted that the assumption (a) applied in the analysis of a classical suspension bridge may sometimes be unacceptable. Admittedly, the absolutely flexible cable is just a theoretical idealisation. Cables of suspension bridges, depending on their cross-sections, always have a certain bending stiffness $\left(E_{\mathrm{c}} J_{\mathrm{c}}>0\right)$, and neglecting it may lead to inaccuracies of various extent (Furst et al. 2001; Gimsing 1997). Moreover, the rigid cables are often suggested for stabilisation of the initial form of the modern suspension bridges. Such cables can be made from standard steel profiles or with welded crosssections. Accurate calculation methods for the analysis of the behaviour of suspension bridges with a rigid cable are practically unavailable. A simple and at the same time efficient engineering technique is proposed by Grigorjeva et al. (2006). This technique uses the girder model. Under this assumption, the equilibrium condition of displacements of the cable and girder is formulated for two points of the entire span only. It is necessary to develop a more accurate technique for the analysis of suspension bridges with a rigid cable.

It is known that during assembly the rigid cable can be shaped so that it would carry the entire dead load as an absolutely flexible cable and the live load like a rigid cable (Kirsanov 1990; Moskalev \& Popova 2003). Analysis of such bridge will be discussed below. The initial equilibrium condition of the rigid cable subjected to load $g$ may be formulated using equation (1). Assuming bending stiffness of cable $E_{\mathrm{c}} J_{\mathrm{c}}>0$, application of the live load $p_{\mathrm{c}}$ will cause bending moment $m_{\mathrm{c}}(x)$ extra to axial force. The equilibrium equation can be written as follows:

$$
\begin{gathered}
H\left[z_{0}(x)+w(x)\right]+m_{\mathrm{c}}(x)+M_{\mathrm{c}, \mathrm{g}+\mathrm{p}}(x)=0 ; \\
m_{\mathrm{c}}(x)=-E_{\mathrm{c}} J_{\mathrm{c}} \cdot w^{\prime \prime}(x) .
\end{gathered}
$$

The equilibrium condition of the stiffening girder subjected to a part of the live load $p_{b}$ remains the same as in the case of a classical bridge and is defined by equation (3). Considering expressions (9) and (3), we can write the constitutive differential equation:

$$
\begin{gathered}
E J \cdot w^{\prime \prime}(x)-H\left[z_{0}(x)+w(x)\right]+M_{\mathrm{g}+\mathrm{p}}(x)=0 ; \\
E J=E_{\mathrm{b}} J_{\mathrm{b}}+E_{\mathrm{c}} J_{\mathrm{c}} .
\end{gathered}
$$

The equation above is equivalent to the equilibrium condition (4) obtained for a classical bridge. However, the analysed bridge possesses some extra stiffness. Obviously, the displacements of such bridge under the same conditions would be smaller than of a classical bridge (which has ideally flexural main cables). If the bridge is subjected to uniformly distributed loading, then equation (10) can be solved similarly to equation (7); only the flexibility parameter will be defined, taking into consideration the rigidity of the cable: $k^{2}=H /\left(E_{\mathrm{b}} J_{\mathrm{b}}+E_{\mathrm{c}} J_{\mathrm{c}}\right)$.

It should be pointed out that the behaviour of a suspension bridge may be regulated by changing the values of the bending stiffness of the girder and the cable. If from the condition of the serviceability limit state, the bending stiffness of the bridge $E J=E_{\mathrm{b}} J_{\mathrm{b}}+E_{\mathrm{c}} J_{\mathrm{c}}$ is known, a rational ratio of the bending stiffness of the cable and the girder $n=E_{\mathrm{c}} J_{\mathrm{c}} / E_{\mathrm{b}} J_{\mathrm{b}}$ can be selected, and such rational ratio would ensure the lowest stresses in the structural elements of the bridge. The flexibility parameter may be expressed as $k^{2}=H / E_{\mathrm{b}} J_{\mathrm{b}}(1+n)$. The procedure of iterative calculations for a suspension bridge with a rigid cable is the same as that for a classical bridge. The bending moments will distribute between the stiffening girder and the cable depending on the stiffness ratio $n$.

\subsection{Discrete model for a classical suspension bridge}

The assumption that the distance between the hangers affects the uniformly distributed load that acts on the cable is not always applicable in calculations. In certain cases there may be only a few hangers; moreover, concentrated forces may act on the stiffening girder. In such cases a bridge must be analysed using the discrete model. The scheme of a girder-stiffened suspension bridge is presented in Fig. c.

The initial vertical load $F_{0 \mathrm{i}}$ is fully balanced by the cable and pre-stresses it. For calculating the cable force $H_{0}$ we may use the following expression:

$$
H_{0}=\frac{a_{0} \sum_{\mathrm{i}=1}^{\mathrm{n}} F_{0 i}\left(l-x_{\mathrm{i}}\right)}{l\left(z_{0}-z_{1}\right)+a_{0}\left(z_{\mathrm{n}+1}-z_{0}\right)} .
$$

Part of the additional load $P$ is balanced by the cable and the rest of it is balanced by the stiffening girder. The equation that describes the deflection of the girder can be written as follows:

$$
\begin{aligned}
w(x)= & w_{0}+\varphi_{0} x-M \frac{(x-a)^{2} H(x-a)}{2 E_{\mathrm{b}} I_{\mathrm{b}}}+ \\
& F \frac{(x-b)^{3} H(x-b)}{6 E_{\mathrm{b}} I_{\mathrm{b}}}+ \\
& p \frac{(x-c)^{4} H(x-c)-(x-d)^{4} H(x-d)}{24 E_{\mathrm{b}} I_{\mathrm{b}}} .
\end{aligned}
$$

Here $E_{b} I_{b}$ is the flexural stiffness of the girder; $w_{0}$ is the vertical displacement at the first point of the girder; $\varphi_{0}$ is the angle of rotation at the first point of the girder; $a, b, c$ and $d$ are the coordinates of the points of the application of forces; and $H(x)$ is the Heaviside's function.

Equation (12) can be used for calculating the deflection of the bridge subjected to complex action of external bending moments $M$, axial forces $F$, and uniformly distributed loading $p$.

In the case of vertical pylons, the horizontal displacements of the supporting nodes of the cable may be defined as

$$
u_{0}=u_{n+1}=\frac{\left(H-H_{0}\right) L_{\mathrm{a}}}{E_{\mathrm{a}} A_{\mathrm{a}} \cos ^{3} \alpha}=B \frac{H-H_{0}}{E_{\mathrm{a}} A_{\mathrm{a}} \cos ^{2} \alpha} .
$$


Here $L_{\mathrm{a}}$ is the length of the anchor cable and $\alpha$ is the angle of inclination of the anchor cable (see Fig. c).

Let us consider only the stiffening girder. Displacements of each hanger joint and support point can be found using the following equation:

$$
\begin{aligned}
w_{\mathrm{m}}= & w_{0}+\varphi_{0} x_{\mathrm{m}}+\sum_{\mathrm{i}=1}^{\mathrm{m}-1} \frac{F_{\mathrm{i}}\left(x_{\mathrm{m}}-x_{\mathrm{i}}\right)+V \cdot x_{\mathrm{m}}^{3}}{6 E_{\mathrm{b}} I_{\mathrm{b}}}- \\
& M \frac{(x-a)^{2} H(x-a)}{2 E_{\mathrm{b}} I_{\mathrm{b}}}+F \frac{(x-b)^{3} H(x-b)}{6 E_{\mathrm{b}} I_{\mathrm{b}}}+ \\
& p \frac{(x-c)^{4} H(x-c)-(x-d)^{4} H(x-d)}{24 E_{\mathrm{b}} I_{\mathrm{b}}} .
\end{aligned}
$$

Here $F_{\mathrm{i}}$ is the internal force in the $i$-th hanger and $V$ is the vertical reaction in the support.

We obtain $n+1$ linear equations for calculating $F_{\mathrm{i}}$, but there are $n+2$ unknown parameters: $F_{1}, F_{2} \ldots F_{\underline{n}}, V$, and $\varphi_{0}$. An extra equation can be written from the moment equilibrium condition upon one of the supports as follows:

$$
\sum_{\mathrm{i}=1}^{\mathrm{n}}\left(L-x_{\mathrm{i}}\right)+V \cdot L+M_{\mathrm{P}}=0 .
$$

Here $M_{\mathrm{P}}$ is the bending moment induced the external loading in the support and $L$ is the span of the suspension bridge (see Fig.).

It becomes evident that it is reasonable to converge all the linearly interdependent components into a uniform linear equation system, which thereafter will be dependent on the cable's internal force $H$. Thus, optimisation of the solution process is aimed at choosing of the function $H$. When placing the displacements calculated from the linear equation system into the expression linking the elongation of the cable and the displacements and the $H$ found in its solution equals the $H$ used for compiling the linear equation system.

\section{Concluding remarks}

The article has analysed classical suspension bridges that consist of a flexible cable and a stiffening girder, as well as a modern bridge structures with a rigid cable (having non-zero flexural stiffness) that is used for stabilisation of the displacements of kinematic origin. The equilibrium conditions of a suspension bridge both with a flexible or rigid cables were discussed in the light of an assembly sequence of such bridges.

The concept of a fictitious displacement was introduced to come up with the expressions for the calculation of displacements and internal forces of such bridges. It has been determined that the derived equations are equivalent to the equations used in the calculation of displacements for suspension cables with bending stiffness. The derived expressions show that a bridge with a rigid cable will have smaller displacements than a classical bridge under the same conditions. It must be noted that the state of stress-strain of a suspension bridge may be regulated by changing the values of the bending stiffness of the stiffening girder and the cable.
The article also presents a discrete calculation model for classical suspension bridges. The model considers the effect of hangers and concentrated forces on displacements and action-effects of the bridge. The equilibrium conditions of such bridges and the iterative calculation are discussed.

\section{Acknowledgement}

The authors gratefully acknowledge the financial support provided by the Research Council of Lithuania, and by the complementary financial support provided by the Agency of International Programs of Scientific and Technology Development in Lithuania.

\section{References}

Cobo del Arco, D.; Aparicio, A. C. 2001. Preliminary static analysis of suspension bridges, Engineering Structures 23(9): 1096-1103. doi:10.1016/S0141-0296(01)00009-8

Gimsing, N. J. 1997. Cable suported bridges - Concept and design. $2^{\text {nd }}$ edition. Chichester: John Wiley \& Sons. $471 \mathrm{p}$.

Grigorjeva, T.; Juozapaitis, A.; Kamaitis, Z. 2006. Simplified engineering design method of suspension bridges with rigid cables under action of symmetrical and asymmetrical loads, The Baltic Journal of Road and Bridge Engineering 1(1): 11-20.

Furst, A.; Marti, P.; Ganz, H. R. 2001. Bending of stay cables, Structural Engineering International 11(1): 42-46.

Jennings, A. 1987. Deflection theory analysis of different cable profiles for suspension bridges, Engineering Structures 9(2): 84-94. doi:10.1016/0141-0296(87)90002-2

Juozapaitis, A.; Norkus, A. 2004. Displacement analysis of assymetrical loaded cable, Journal of Civil Engineering and Management 10(4): 277-284.

Juozapaitis, A.; Vainiūnas, P.; Kaklauskas, G. 2006. A new steel structural system of a suspension pedestrian bridge, Journal of Constructional Steel Research 62(12): 12571263. doi:10.1016/j.jcsr.2006.04.023

Juozapaitis, A.; Norkus, A.; Vainiūnas, P. 2008. Shape stabilization of steel suspension bridge, The Baltic Journal of Road and Bridge Engineering 3(3): 137-144. doi:10.3846/1822-427X.2008.3.137-144

Kala, Z. 2008. Fuzzy probability analysis of the fatigue resistance of steel structural members under bending, Journal of Civil Engineering and Management 14(1): 67-72. doi:10.3846/1392-3730.2008.14.67-72

Kulbach, V. 2007. Cable structures. Design and static analysis. Tallin: Estonian Academy Publishers. 224 p.

Kulbach, V.; Idnurm, J.; Idnurm, S. 2002. Discrete and continuous modeling of suspension bridge, in Proc. of the Estonian Academy of Sciences Engineering. Tallinn: EAS, 2: $121-133$.

Mang, H. A. 2009. On contemporary computational mechanics, Journal of Civil Engineering and Management 15(1): 113-128. doi:10.3846/1392-3730.2009.15.113-128

Nevaril, A.; Kytyr, J. 2001. FEM analysis of bridge-type cable system, in Proc. of IABSE Conference Cable Supported Bridges - Challenging Technical Limits, 12-14 June 2001, Seoul, Korea. IABSE Reports 84: 154-155.

Prato, C. A.; Ceballos, M. A. 2003. Dynamic bending stresses near the ends of parallel bundle stay cables, Structural Engineering International 13(1): 42-46. doi: $10.2749 / 101686603777965008$ 
Ryall, M. J.; Parke, G. A. R.; Harding, J. E. 2000. Manual of bridges engineering. London: Tomas Telford Ltd. 1007 p.

Troyano, L. F. 2003. Bridge engineering. A global perspective. London: Tomas Telford Ltd. 775 p.

Wollman, G. P. 2001. Preliminary analysis of suspension bridges, Journal of Bridge Engineering 6(4): 227-233. doi:10.1061/(ASCE)1084-0702(2001)6:4(227)

Качурин, В; Брагин, А.; Ерунов, Б. 1971. Проектирование висячих и вантовых мостов [Katchurin, V.; Bragin, A.; Erunov, B. Design of suspension and cable-stayed bridges]. Москва: Транспорт. 280 с.

Кирсанов, Н. М. 1990. Висячие покрытия производственных зданий [Kirsanov, N. M. Suspension structures for industrial buildings]. Москва: Стройиздат. $128 \mathrm{c}$.
Москалев, Н. С.; Попова, Р. А. 2003. Стальные конструкции легких зданий [Moskalev, N. S.; Popova, R. A. Steel structures of light-weight buildings]. Москва: АCB. $216 \mathrm{c}$.

Мущанов, В. Ф.; Руднева, И. Н.; Прядко, Ю. М. 2005. Экспериментальное исследование блока висячих ферм при действии неравновесных нагрузок [Muschanov, V. F.; Rudneva, I. N.; Pryadko, Yu. M. Experimental investigation of suspended trusses unit at unbalanced load action], Металлические конструкиии [Steel Structures] 8(1): 35-42.

\section{KABAMŲJŲ TILTŲ SU LANKSČIU IR STANDŽIU LYNAIS NETIESINIS SKAIČIAVIMAS}

\section{A. Juozapaitis, S. Idnurm, G. Kaklauskas, J. Idnurm, V. Gribniak}

S a n tra k a

Viena iš pagrindinių kabamųjų tiltų projektavimo problemų yra pradinės jų formos stabilizavimas. Kabamųjų tiltų deformatyvumą lemia iš esmès ne tiek tampriosios deformacijos, kiek asimetrinių apkrovų sukelti kinematiniai kabamojo lyno poslinkiai. Yra žinomi kabamieji tiltai, kuriu pradinei formai stabilizuoti siūloma vietoje iprastinių lanksčiųju lynų taikyti vadinamuosius standžius lynus. Tokių kabamųų tiltų su standžiais lynais skaičiavimo metodai nėa iki galo parengti. Klasikiniams tiltams su lanksčiu lynu skaičiuoti taikomi daugiausia kontinualūs modeliai, kurie esant tam tikrai tilto sandarai ar veikiant sutelktoms apkrovoms nėra pakankamai tikslūs. Straipsnyje pateikiamos analizinès išraiškos kabamųjų tiltų su standžiu lynu iražzoms ir poslinkiams apskaičiuoti, aptariamas diskretusis klasikinių kabamujų tiltų skaičiavimo modelis.

Reikšminiai žodžiai: kabamasis tiltas, lankstus lynas, standus lynas, netiesinè analizè, kontinualus ir diskretinis modeliai, irą̌zos ir poslinkiai.

Algirdas JUOZAPAITIS. Assoc. Prof., PhD. Dept of Bridges and Special Structures. Vilnius Gediminas Technical University, Vilnius, Lithuania. Author and coauthor of over 40 scientific articles. Research interests: non-linear analysis of bridges and special structures.

Siim IDNURM. PhD, Prof. at the Department of Transportation, Tallinn University of Technology. Research interests: girder-stiffened cable and suspension bridges.

Gintaris KAKLAUSKAS. Professor and the Head of Dept of Bridges and Special Structures at VGTU, Lithuania. He received his engineering degree, $\mathrm{PhD}$ and Dr Habil (Dr Sc) from VGTU. Research interests include various topics of reinforced concrete, particularly constitutive modelling and numerical simulation of reinforced concrete structures. Recipient of Fulbright Fellowship (for research work at the University of Illinois, Urbana-Champaign, 1996) and Marie Curie Fellowship (experienced researcher category, 2002-2003). Member of the FIB Task Group 4.1 "Serviceability Models".

Juhan IDNURM. PhD, Assoc. Prof. at the Department of Transportation, Tallinn University of Technology. Research interests: girder-stiffened cable and suspension bridges.

Viktor GRIBNIAK. Researcher at the Dept of Bridges and Special Structures, VGTU, Lithuania. BSc (2001, Civil Engineering), MSc (2003, Building Structures) and PhD (2009, Civil Engineering) from VGTU. A study visit to Polytechnico di Torino (2003). Author of a number of papers. Research interests: mathematical modelling, statistical analysis and numerical simulation of concrete structures. 